\title{
PREPARASI KARBON TEREMBAN OKSIDA COBALT DARI LIMBAH KULIT MANGGIS SEBAGAI ADSORBEN PENJERAP ETILEN UNTUK PENGAWETAN BUAH
}

\author{
Nur Indah Fajar Mukti, Imam Prasetyo*) dan Aswati Mindaryani \\ Jurusan Teknik Kimia, Fakultas Teknik, UGM \\ Jl. Grafika 2, Kampus UGM, Yogyakarta, Telp. 0274-902171, Fax. 0274-902170 \\ ${ }^{*}$ Penulis korespondensi : imampras@ ugm.ac.id
}

\begin{abstract}
PREPARATION OF CARBON SUPPORTED COBALT OXIDE FROM WASTE OF MANGOSTEEN PEELS AS ETHYLENE SCAVANGER FOR FRUIT PRESERVATION. Ethylene is a compound produced naturally by fruit that can accelerate the maturity of the fruit. Controlling ethylene gas as a product of metabolism of fruit during storage will prolong the shelf life of the fruit. Controlling ethylene gas is carried out by adsorption process using carbon-impregnated cobalt oxide. In this study, carbon as a support made by pyrolysis of extraction waste of mangosteen peel at a temperature of $850^{\circ} \mathrm{C}$ for 15 minutes. Furthermore, the process of impregnating of cobalt oxide into the carbon pore network was carried out by using the incipient wetness impregnation method by adding a cobalt salt solution into the carbon pore network, followed by heating at a temperature of $110^{\circ} \mathrm{C}$ for 8 hours and calcination at a temperature of $200^{\circ} \mathrm{C}$ for 6 hours. Ethylene adsorption test performed at $30^{\circ} \mathrm{C}$ using a static volumetric test. While Cavendish banana fruit preservation process was carried out at ambient temperature $\left(20-32^{\circ} \mathrm{C}\right)$ by observing the changing of skin color from day to day. Adsorption test results showed that the ethylene uptake increased with the increasing of the composition of cobalt oxide on the carbon surface. The highest ethylene uptake of $6.094 \mathrm{mmol} /(\mathrm{gram}$ of adsorbent) was obtained from adsorption of ethylene using carbon-impregnated $30 \%$ cobalt oxide. Fruit preservation process indicated that the increasing of amount of adsorbent can improve the shelf life of bananas Cavendish. The highest result was obtained from the addition of 15 grams of carbon-impregnated cobalt oxide and silica gel that can extend the shelf life of bananas Cavendish for 15 days.
\end{abstract}

Keywords: adsorption; carbon; cobalt oxide; ethylene; impregnation

\begin{abstract}
Abstrak
Etilen merupakan senyawa yang dihasilkan secara alami oleh buah yang dapat mempercepat kematangan pada buah. Pengontrolan gas etilen sebagai produk metabolisme buah selama penyimpanan akan memperpanjang masa simpan buah tersebut. Pengontrolan gas etilen dilakukan dengan proses adsorpsi menggunakan karbon teremban oksida cobalt. Pada penelitian ini, karbon sebagai pengemban dibuat dari pirolisis limbah kulit manggis sisa ekstraksi pada suhu $850^{\circ} \mathrm{C}$ selama 15 menit. Selanjutnya, proses pengembanan oksida cobalt pada permukaan karbon dibuat melalui proses impregnasi dengan incipient wetness method yang dilakukan dengan menambahkan larutan garam cobalt ke dalam jaringan pori karbon yang dilanjutkan dengan pemanasan pada suhu $110^{\circ} \mathrm{C}$ selama 8 jam dan kalsinasi pada suhu $200^{\circ} \mathrm{C}$ selama 6 jam. Uji adsorpsi etilen dilakukan pada suhu $30^{\circ} \mathrm{C}$ menggunakan alat uji static volumetric. Sedangkan proses pengawetan buah pisang Cavendish dilakukan pada suhu lingkungan $\left(20-32^{\circ} \mathrm{C}\right)$ dengan mengamati perubahan warna kulitnya dari hari ke hari. Hasil uji adsorpsi menunjukkan bahwa semakin banyak komposisi oksida cobalt pada permukaan karbon akan meningkatkan kapasitas penjerapan terhadap etilen. Hasil tertinggi sebesar 6,094 mmol/(gram adsorben) diperoleh dari adsorpsi etilen menggunakan karbon teremban 30\% oksida cobalt. Dari proses pengawetan buah menunjukkan bahwa jumlah karbon teremban oksida cobalt yang semakin meningkat dapat meningkatkan umur simpan dari buah pisang Cavendish. Hasil tertinggi diperoleh dari penambahan 15 gram karbon teremban cobalt dan silica gel dapat memperpanjang umur simpan buah pisang Cavendish selama 15 hari.
\end{abstract}

Kata kunci: adsorpsi; karbon; oksida cobalt; etilen; impregnasi 
How to Cite This Article: Mukti, N.I.F., Prasetyo, I., dan Mindaryani, A., (2015), Preparasi Karbon Teremban Oksida Cobalt dari Limbah Kulit Manggis sebagai Adsorben Penjerap Etilen untuk Pengawetan Buah, Reaktor, 15(3), 165-174, http://dx.doi.org/ 10.14710/reaktor.15.3.165-174

\section{PENDAHULUAN}

Metode pengawetan buah untuk memperpanjang umur simpan dari buah pasca panen telah banyak dilakukan. Beberapa metode yang dilakukan untuk memperpanjang umur simpan buah adalah dengan memperlambat pematangan buah yang dilakukan dengan memperlambat respirasi dan menjerap gas etilen yang terbentuk. Pengurangan laju respirasi dilakukan dengan meminimalkan kontak antara udara dengan buah yang dapat dilakukan diantaranya dengan teknik pelapisan (coating), penyimpanan suhu rendah (pendinginan), atau memodifikasi ruang penyimpan (Kristianingrum, 2007). Sedangkan pengurangan gas etilen dapat dilakukan dengan cara penyemprotan enzim penghambat produksi etilen pada produk (Setyadjit dkk., 2012), oksidasi etilen dengan $\mathrm{KMnO}_{4}$ (Kristianingrum, 2007), atau penjerapan etilen dengan material berpori berbasis silica seperti zeolit (Sue-aok dkk., 2010; Smith dkk., 2009) maupun berbasis karbon seperti karbon aktif (Bailen dkk., 2007; Li dkk., 2013; Cao dkk., 2014).

Etilen merupakan suatu senyawa yang dihasilkan secara alami oleh buah yang dapat mempercepat kematangan pada buah. Keberadaan etilen pada tempat penyimpanan buah pasca panen akan dapat mempercepat kematangan dan pembusukan buah. Buah yang cepat busuk selama penyimpanan akan menurunkan nilai jualnya. Salah satu usaha untuk mengatasi masalah tersebut dapat dilakukan dengan cara mengurangi jumlah gas etilen. Pengontrolan gas etilen yang dihasilkan oleh buah dan sayur sebagai produk metabolisme setelah pengemasan akan memperpanjang masa simpan produk hortikultura yang disimpan (Smith dkk., 2009).

Pada penelitian ini pengontrolan gas etilen akan dilakukan dengan proses adsorpsi menggunakan adsorben berbasis karbon (Kristianingrum, 2007). Adsorben berbasis karbon seperti karbon aktif tidak dapat digunakan langsung untuk menjerap etilen. Untuk dapat digunakan dalam menjerap etilen diperlukan modifikasi pada permukaan karbon dengan penambahan oksida logam pada permukaannya. Proses modifikasi permukaan karbon dengan menambahkan oksida logam dilakukan dengan mengadopsi dari proses pembuatan katalis heterogen. Pada penelitian ini, proses modifikasi permukaan karbon dilakukan dengan proses impregnasi menggunakan incipient wetness method. Incipient wetnees impregnation method merupakan metode impregnasi dimana volume larutan yang digunakan sama dengan volume dari rongga pori karbon.

Penelitian ini diawali dengan pembuatan material karbon berpori yang akan digunakan sebagai pengemban oksida cobalt. Pembuatan karbon berpori dari material yang berasal dari lignoselulosa telah banyak dipelajari. Diantaranya pembuatan karbon berpori dari tempurung kelapa, kulit manggis, bonggol jagung, ampas tebu, kulit durian (Chen dkk., 2011; Okhovat dkk., 2012; Bujang, 2014; Yang dkk., 2010). Dari beberapa penelitian yang telah dilakukan, kulit manggis memiliki potensi untuk digunakan sebagai bahan baku pembuatan karbon berpori dengan luas permukaan cukup tinggi sehingga dapat digunakan sebagai adsorben yang memiliki kapasitas yang besar (Chen dkk., 2011; Ahmad dan Alrozi, 2010).

Karakteristik kulit manggis, tempurung kelapa dan bonggol jagung dapat dilihat pada Tabel 1 (Chen, 2011; Saidur, 2011; Shawal, 2014). Jika dilihat dari hasil proximate dan ultimate analysis dapat terlihat bahwa kulit manggis memiliki karakteristik yang hampir sama seperti tempurung kelapa dan bonggol jagung. Dimana telah diketahui bahwa tempurung kelapa dan bonggol jagung dapat menghasilkan karbon berpori dengan luas permukaan yang cukup tinggi.

Dari Tabel 1 juga dapat diketahui bahwa kulit manggis memiliki kandungan karbon yang cukup tinggi seperti halnya tempurung kelapa dan bonggol jagung yaitu sekitar 48,81\%. Selain itu, kulit manggis memiliki kandungan fixed carbon yang lebih tinggi dibandingkan tempurung kelapa dan bonggol jagung. Kandungan fixed carbon ini menunjukkan jumlah karbon maksimum yang dapat dihasilkan dari suatu biomassa setelah proses pirolisis. Jumlah fixed carbon yang tinggi dikarenakan suatu biomassa memiliki kandungan lignin yang cukup tinggi. Cagnon (2009) mengatakan bahwa komposisi lignin yang semakin tinggi akan menghasilkan jumlah karbon yang semakin banyak. Jika dilihat komposisi lignoselulosanya bonggol jagung memiliki komposisi terbesar berupa selulosa dan hemiselulosa yang dominan. Jadi meskipun bonggol jagung dapat menghasilkan luas permukaan yang tinggi namun jumlah karbon yang dihasilkan sedikit. Sedangkan komposisi lignoselulosa dari tempurung kelapa memiliki komposisi lignin yang lebih dominan sehingga mampu menghasilkan jumlah karbon yang lebih banyak. Dengan melihat jumlah fixed carbon dari kulit manggis yang sedikit lebih tinggi dari tempurung kelapa maka dapat disimpulkan bahwa kulit manggis memiliki kandungan lignin yang cukup tinggi. Dari karakteristik yang dimilikinya maka kulit manggis ini berpotensi untuk dijadikan bahan baku karbon berpori dengan luas permukaan yang tinggi dan menghasilkan jumlah karbon yang cukup banyak sehingga akan menguntungkan dari sisi ekonomi. 
Tabel 1. Proximate analysis dan biochemical properties dari berbagai biomassa

\begin{tabular}{|c|c|c|c|}
\hline \multirow[t]{2}{*}{ Parameter } & & \multicolumn{2}{|c|}{ Biomassa } \\
\hline & Kulit Manggis & Tempurung kelapa & Bonggol Jagung \\
\hline \multicolumn{4}{|l|}{$\begin{array}{l}\text { Proximate Analysis, \%w/w } \\
\text { (basis kering) }\end{array}$} \\
\hline $\mathrm{abu}$ & 2,73 & 1,16 & 1,10 \\
\hline volatil & 70,66 & 74,5 & 87,40 \\
\hline Fixed carbon & 26,60 & 24,34 & 11,50 \\
\hline \multicolumn{4}{|l|}{$\begin{array}{l}\text { Ultimate Analysis), \%w/w } \\
\text { (basis kering) }\end{array}$} \\
\hline Karbon & 48,81 & 49,62 & 46.51 \\
\hline Oksigen & 42,69 & 42,75 & 44.13 \\
\hline Hidrogen & 5,73 & 7,31 & 5.68 \\
\hline Nitrogen & 0,44 & 0,22 & 0.49 \\
\hline \multicolumn{4}{|l|}{ Analisis Komponen, $\% w / w$} \\
\hline Selulosa & - & 36,3 & 52,49 \\
\hline Hemiselulosa & - & 25,1 & 32,32 \\
\hline Lignin & - & 28,7 & 15,19 \\
\hline Sumber & Chen dkk., 2011 & Shawal dkk., 2014 & Saidur dkk., 2011 \\
\hline
\end{tabular}

Tabel 2. Proximate analysis dan kadar lignoselulosa limbah sisa ekstraksi kulit manggis

\begin{tabular}{lclc}
\hline \multicolumn{2}{c}{ Proximate Analysis } & \multicolumn{2}{c}{ Komposisi Lignoselulosa } \\
\hline Komponen & $\begin{array}{c}\text { Komposisi, } \\
\%\end{array}$ & Komponen & $\begin{array}{c}\text { Komposisi, } \\
\%\end{array}$ \\
\hline Air & 3,58 & Selulosa & 26,22 \\
Abu & 1,85 & Hemiselulosa & 15,39 \\
Volatile & 62,28 & Lignin & 48,52 \\
matter & & & \\
Fixed & 32,29 & & \\
carbon & & & \\
\hline
\end{tabular}

Bahan baku pembuatan karbon berpori penyangga oksida logam yang digunakan pada penelitian ini adalah kulit manggis yang telah mengalami proses ekstraksi atau telah diambil komponen antioksidannya. Hal ini didasarkan pada penelitian sebelumnya yang mengatakan bahwa karbon berpori dari limbah sisa ekstraksi kulit manggis dapat memberikan luas permukaan yang cukup tinggi. Selain itu, karbon berpori yang dihasilkan dari limbah sisa ekstraksi kulit manggis merupakan karbon mesopori (Mukti dkk., 2015). Karbon mesopori diharapkan dapat memudahkan proses difusi garam cobalt yang berukuran 7-8 $\AA$ di dalam jaringan pori karbon. Karbon mesopori merupakan karbon dengan ukuran 2-50 nm, menurut klasifikasi ukuran pori IUPAC.

Pada penelitian ini akan mempelajari pembuatan karbon teremban oksida cobalt untuk dapat digunakan sebagai adsorben penjerap etilen pada proses pengawetan buah. Karbon berpori sebagai penyangga oksida cobalt diperoleh melalui proses pirolisis limbah sisa ekstraksi kulit manggis dengan penambahan steam untuk meningkatkan porositasnya. Penelitian ini bertujuan untuk mengetahui pengaruh dari perbedaan garam cobalt, komposisi cobalt dan suhu adsorpsi terhadap kapasitas penjerapan etilen. Selain itu, dipelajari juga pengaruh penambahan karbon teremban oksida cobalt pada penyimpanan buah pisang Cavendish.

\section{METODE PENELITIAN Bahan}

Bahan yang digunakan dalam penelitian ini terdiri dari bahan baku utama dan bahan baku pendukung. Bahan baku utama yang digunakan diantaranya adalah serbuk kulit manggis berukuran 180-355 $\mu \mathrm{m}$ yang diperoleh dari Bina Agro Mandiri, Bantul, D.I. Yogyakarta dengan komposisi terlihat pada Tabel 2, cobalt nitrat hexahydrate dengan kemurnian 99,98\%, gas etilen dengan kemurnian 99,98\% dan pisang Cavendish. Bahan baku pendukung yang digunakan diantaranya etanol dengan kadar $96 \%$ dan isopropil alcohol.

\section{Cara Penelitian}

Pembuatan karbon berpori dari limbah sisa ekstraksi kulit manggis

Karbon berpori dibuat melalui ekstraksi serbuk kulit manggis yang dilakukan dengan melarutkan dan mengaduk serbuk kulit manggis pada etanol 96\% selama 24 jam. Dilanjutkan dengan memisahkan residu kulit manggis dengan larutan ekstraknya dan pengeringan menggunakan oven pada suhu $110^{\circ} \mathrm{C}$ selama 6 jam. Residu sisa ekstraksi dikarbonisasi pada reaktor furnace dengan aliran $\mathrm{N}_{2}$ (inert) dari suhu kamar sampai suhu karbonisasi $575^{\circ} \mathrm{C}$ dan proses ditahan selama 3 jam, dilanjutkan pemanasan sampai suhu $850^{\circ} \mathrm{C}$ dan proses ditahan selama 15 menit dengan mengalirkan gas $\mathrm{N}_{2}$ dan steam. Karbon yang dihasilkan dikarakterisasi dengan Adsorpsi-desorpsi $\mathrm{N}_{2}$ dikarakterisasi menggunakan NOVA 2000 adsorption analyzer (Quantachrome) pada77 K. Luas permukaan spesifik ( $\mathrm{S}$ ) dihitung dari isoterm data pada rentang tekanan relatif $\left(\mathrm{P} / \mathrm{P}_{\mathrm{o}}\right)$ antara 0.05-0.30 dengan model adsorpsi Brunauer-Emmet-Teller (BET) (Do, 1998). 


$$
\frac{\mathrm{P}}{\mathrm{V}_{\mathrm{A}}\left(\mathrm{P}_{0}-\mathrm{P}\right)}=\frac{1}{\mathrm{~V}_{\mathrm{m}} \mathrm{C}_{\mathrm{H}}}+\frac{\mathrm{C}_{\mathrm{H}}-1}{\mathrm{~V}_{\mathrm{m}} \mathrm{C}_{\mathrm{H}}}\left(\frac{\mathrm{P}}{\mathrm{P}_{0}}\right)
$$

Volum pori total $(\mathrm{V})$ diestimasi dari jumlah adsorbat terjerap pada $\mathrm{P} / \mathrm{P}_{\mathrm{o}}$ sebesar 0.99 dan luas permukaan spesifik micro (Smic), volum micro (Vmic) ditentukan menggunakan $t$-plot method (Do, 1998).

$$
\mathrm{t}_{\mathrm{c}}=3,54\left(\frac{5}{2.303 \log \left(\mathrm{P}_{0} / \mathrm{P}\right)}\right)^{1 / 3}
$$

Luas permukaan dan volum pori dari setiap ketebalan, t, sampai batas mikropori $<2 \mathrm{~nm}$ dihitung dengan Persamaan (3) (Do, 1998).

$$
\mathrm{s}_{\mathrm{t}}=\frac{\mathrm{V}_{\mathrm{STP}_{\mathrm{ads}}} \cdot 15,47}{\mathrm{t}_{\mathrm{c}}}
$$

Distribusi ukuran pori dipelajari dengan metode Horvarth-Kawazoe (HK) yang digunakan untuk menggambarkan distribusi pori berukuran mikro dan metode Barret-Joyner-Haleda $(\mathrm{BJH})$ yang digunakan untuk menggambarkan distribusi pori berukuran meso. Persamaan untuk metode HK dapat dilihat pada Persamaan (4) dan untuk metode BJH dapat dilihat pada Persamaan (5) (Barret, 1951; Do, 1998).

\section{Proses Impregnasi Oksida Cobalt pada Permukaan Karbon}

Tahap pertama proses impregnasi dilakukan dengan degassing karbon berpori pada suhu $150^{\circ} \mathrm{C}$ selama 1 jam dalam keadaan vakum. Proses dilanjutkan dengan mengalirkan larutan garam secara perlahan-lahan ke dalam karbon. Kemudian dilakukan pemanasan pada suhu $110^{\circ} \mathrm{C}$ selama 6 jam dan kalsinasi pada suhu $200^{\circ} \mathrm{C}$ selama 6 jam. Variasi komposisi oksida cobalt yang digunakan alah 5\%, $10 \%$, 20\%, dan $30 \%$ berat cobalt terhadap berat karbon. Sedangkan variasi garam yang digunakan adalah $\mathrm{CoCl}_{2}, \mathrm{CoSO}_{4}$ dan $\mathrm{Co}\left(\mathrm{NO}_{3}\right)_{2}$. Variasi komposisi dilakukan untuk mengetahui jumlah cobalt maksimum yang dapat diimpregkan ke dalam karbon berpori. Jumlah komposisi cobalt yang sedikit akan menjerap etilen sedikit, sedangkan jumlah komposisi cobalt yang terlalu banyak akan dapat menyebabkan aglomerasi logam pada permukaan karbon yang menyebabkan efektifitas penjerapannya menjadi berkurang. Variasi garam cobalt dilakukan untuk mengetahui garam yang paling mudah terdekomposisi menjadi oksida cobalt pada proses kalsinasi (Mukti, 2015). Penamaan hasil impregnasi cobalt pada karbon masing-masing yaitu C, C-5Co, C-10Co, C-20Co dan C-30Co disesuaikan dengan komposisi cobalt yang teremban dan $\mathrm{C}-\mathrm{Co}\left(\mathrm{NO}_{3}\right)_{2}, \mathrm{C}-\mathrm{CoCl}_{2}, \mathrm{C}-\mathrm{CoSO}_{4}$ dan C$\mathrm{KMnO}_{4}$ disesuaikan dengan garam yang digunakan.

\section{Kinerja Adsorben dalam Penjerapan Etilen}

Uji adsorpsi etilen pada adsorben yang dihasilkan dilakukan untuk mengetahui kemampuan kinerja dari adsorben tersebut dalam menjerap etilen. Uji adsorpsi dilakukan menggunakan alat uji adsorpsi secara static volumetric yang dirangkai menggunakan ultra high vacuum valves and fittings Swagelok ${ }^{\circledR}$. Rangkaian alat uji adsorspsi dapat dilihat pada Gambar 1. Tahap persiapan dilakukan dengan degassing material karbon pada suhu $150{ }^{\circ} \mathrm{C}$ selama \pm 6 jam. Tahap selanjutnya adalah melakukan uji adsorpsi gas etilen secara volumetric. Sistem adsorpsi dikondisikan pada suhu $30^{\circ} \mathrm{C}$. Uji adsorpsi gas secara volumetric diawali dengan memastikan semua valve dalam keadaan tertutup (V1, V2 dan V3). Untuk mengisi loading cell, valve no V1 dibuka secara perlahan hingga dicapai tekanan yang diinginkan dan dicatat sebagai $\mathrm{P}_{1}$, lalu ditutup kembali. Selanjutnya untuk melakukan proses adsorpsi, valve no. V2 dibuka dan diamati penurunan tekanan di alat pengukur tekanan hingga diperoleh tekanan dalam keadaan setimbang dan dicatat sebagai $\mathrm{P}_{2}$. Kesetimbangan adsorpsi ditunjukkan dengan stabilnya tekanan di dalam sistem adsorpsi. Untuk melanjutkan pada titik kesetimbangan berikutnya, valve no. V2 ditutup kembali dan langkah-langkah tersebut diulangi sampai tekanan maksimal yang mampu dioperasikan $( \pm 1,2$ atm) (Do, 1998).

Beberapa model kesetimbangan adsorpsi digunakan untuk mengevaluasi data hasil percobaan, diantaranya (Do, 1998):

Persamaan Langmuir : $\mathrm{C}_{\mu}=\mathrm{C}_{\mu \mathrm{s}}\left(\frac{\mathrm{bP}}{1+\mathrm{bP}}\right)$

Persamaan Freundlich : $\mathrm{C}_{\mu}=\mathrm{KP}^{1 / \mathrm{n}}$

Persamaan Unilan : $C_{\mu}=\frac{C_{\mu S}}{2 s} \ln \left(\frac{1+b e^{S} P}{1+b e^{-S} P}\right)$

Persamaan Sips : $C_{\mu}=C_{\mu S} \frac{(b P)^{1 / n}}{1+(b P)^{1 / n}}$

Persamaan Toth : $C_{\mu}=C_{\mu S} \frac{b P}{\left[1+(b P)^{t}\right]^{1 / t}}$

\section{HASIL DAN PEMBAHASAN \\ Karakteristik Karbon Berpori}

Struktur dari suatu karbon berpori yang meliputi luas permukaan spesifik, diameter pori ratarata dan volume pori disajikan pada Tabel 3.

Dari Tabel 3 dapat diketahui bahwa karbon berpori yang dihasilkan dari limbah sisa ekstraksi kulit manggis merupakan karbon mesopori. Hal tersebut dapat dilihat dari luas permukaan dan volume mesopori lebih dominan dari luas permukaan dan volume mikroporinya. Sedangkan karbon yang

$$
\begin{gathered}
\mathrm{RT} \ln \left(\frac{\mathrm{P}}{\mathrm{P}_{0}}\right)= \\
\mathrm{K} \frac{\mathrm{N}_{\mathrm{S}} \mathrm{A}_{\mathrm{S}}+\mathrm{N}_{\mathrm{A}} \mathrm{A}_{\mathrm{A}}}{\sigma^{4}(1-\mathrm{d})}\left[\frac{\sigma^{4}}{3\left(1-\frac{\mathrm{d}}{2}\right)^{3}}-\frac{\sigma^{10}}{9\left(1-\frac{\mathrm{d}}{2}\right)^{9}}-\frac{\sigma^{4}}{3\left(\frac{\mathrm{d}}{2}\right)^{3}}+\frac{\sigma^{10}}{9\left(\frac{\mathrm{d}}{2}\right)^{9}}\right] \\
\log \left(\frac{\mathrm{P}}{\mathrm{P}_{0}}\right)=\frac{-2 \sigma \mathrm{V}}{8,316 \times 10^{7} \times 2,303 \mathrm{~T}_{\mathrm{k}}}=\frac{-4,14}{\mathrm{r}_{\mathrm{k}}}
\end{gathered}
$$


dihasilkan dari kulit manggis sebelum proses ekstraksi memperlihatkan bahwa karbon tersebut merupakan karbon mikropori yang terlihat dari luas permukaan dan volume mikroporinya yang lebih dominan dari luas permukaan dan volume mesoporinya. Karbon mesopori merupakan karbon dengan ukuran 2-50 nm, sedangkan karbon mikropori merupakan karbon dengan ukuran 0-2 nm, menurut klasifikasi ukuran pori IUPAC (Do, 1998).

Tabel 3. Karakteristik karbon berpori

\begin{tabular}{lcc}
\hline Karakter & $\begin{array}{c}\text { Kulit Manggis } \\
\text { Sisa Ekstraksi }\end{array}$ & $\begin{array}{c}\text { Kulit } \\
\text { Manggis }\end{array}$ \\
\hline $\begin{array}{l}\text { Luas permukaan spesifik } \\
\left(\mathrm{S}_{\mathrm{BET}}\right), \mathrm{m}^{2} / \text { gram }\end{array}$ & 1066,77 & 1184,66 \\
$\begin{array}{l}\text { Luas mikropori }\left(\mathrm{S}_{\text {mic }}\right), \\
\mathrm{m}^{2} / \text { gram }\end{array}$ & 463,16 & 827,32 \\
$\% \mathrm{~S}_{\text {mic }}$ & 43,42 & 69,84 \\
Total volume pori, $\mathrm{cm}^{3} / \mathrm{g}$ & 1,276 & 0,925 \\
Volum mikropori $\left(\mathrm{V}_{\text {mic }}\right)$, & 0,207 & 0,368 \\
$\mathrm{~cm}^{3} / \mathrm{g}$ & 16,22 & 45,08 \\
$\%$ Vmic & 4,79 & 3,13 \\
$\begin{array}{l}\text { Diameter pori rata-rata, } \\
\mathrm{nm}\end{array}$ & & \\
\hline
\end{tabular}

Dari uji proximate analysis dan kadar lignoselulosa untuk kulit manggis dan limbah kulit manggis sisa ekstraksi memiliki karakteristik yang sama namun menghasilkan karakter karbon berpori yang berbeda. Perbedaan yang mendasar dari karakteristik karbon dari limbah sisa ekstraksi kulit manggis dengan karbon dari kulit manggis disebabkan oleh adanya zat-zat dari kulit manggis yang ikut terekstrak dalam etanol selama proses ekstraksi. Zat ekstraktif ini bukan merupakan bagian dari struktur dinding sel namun terdapat dalam rongga sel dengan kisaran jumlah antara 3-8\% dari berat kering bahan baku. Beberapa contoh zat ekstraktif diantaranya berupa getah, resin, lilin, tannin, pati, zat warna, dll (Mukti dkk., 2015). Dari karakteristik tersebut maka dapat disimpulkan bahwa karbon yang dihasilkan dari limbah sisa ekstraksi kulit manggis merupakan karbon mesopori dengan luas permukaan spesifik sebesar $1066,77 \mathrm{~m}^{2} /$ gram dengan diameter rata-rata $4,79 \mathrm{~nm}$.

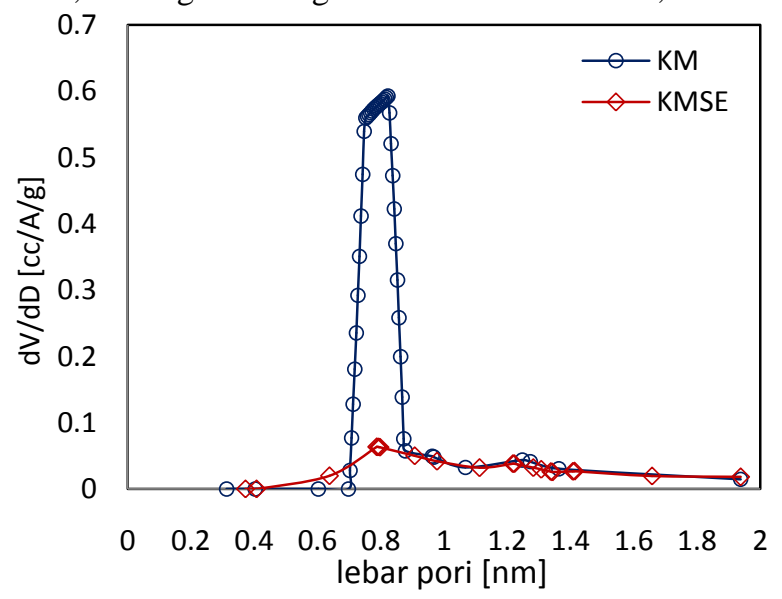

(a)
Sedangkan karbon yang dihasilkan dari kulit manggis merupakan karbon mikropori dengan luas permukaan spesifik sebesar 1184,66 $\mathrm{m}^{2} /$ gram dengan diameter rata-rata $3,13 \mathrm{~nm}$.

Distribusi ukuran pori dari kedua karbon dipelajari menggunakan metode $\mathrm{HK}$ dan metode BJH. Metode HK dapat digunakan untuk menggambarkan distribusi ukuran pori dari material berpori yang memiliki ukuran mikro atau mikropori. Metode HK dikembangkan dari Persamaan yang independen dari Persamaan Kelvin dan menganggap bahwa bentuk pori yang dimiliki karbon berpori tersebut adalah slit (Do, 1998). Sedangkan untuk Metode BJH dikembangkan dari Persamaan Kelvin dengan mengasumsikan pada tekanan relatif $\left(\mathrm{P} / \mathrm{P}_{\mathrm{o}}\right)$ mendekati 1 seluruh pori terisi oleh cairan, maka volum dari pori dan volum yang terjadi kondensasi kapiler dapat diperkirakan. Persamaan untuk distribusi ukuran pori dengan metode $\mathrm{BJH}$ ditentukan dengan dasar pengurangan volum pori dan ketebalan adsorbat yang mengalami kondensasi kapiler karena adanya penurunan tekanan relatif (Barrett dkk., 1951). Metode BJH baik digunakan untuk menggambarkan distribusi ukuran pori antara 2-50 $\mathrm{nm}$ (meso) dengan bentuk pori berupa silinder.

Dilihat dari karakteristik karbon dari kulit manggis dan limbah sisa ekstraksi kulit manggis pada Tabel 2, metode HK baik digunakan untuk menggambarkan distribusi ukuran pori karbon dari kulit manggis karena merupakan karbon mikropori. Sedangkan untuk karbon dari limbah sisa ekstraksi kulit manggis merupakan karbon mesopori sehingga metode $\mathrm{BJH}$ lebih tepat digunakan untuk menggambarkan distribusi ukuran porinya.

Gambar 2(a) merupakan penggambaran distribusi ukuran pori untuk karbon dari kulit manggis dan limbah sisa ekstraksi kulit manggis menggunakan metode HK dan Gambar 2(b) merupakan penggambaran distribusi ukuran pori untuk karbon dari limbah sisa ekstraksi kulit manggis menggunakan metode BJH.

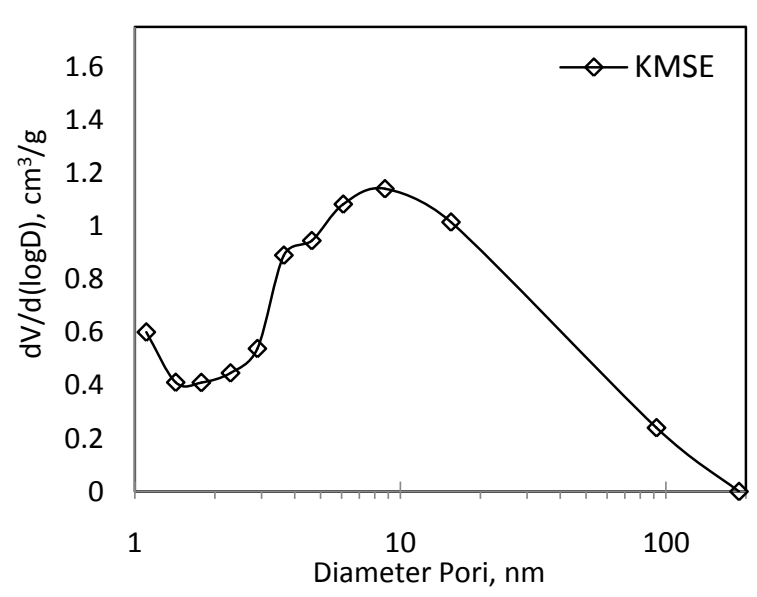

(b)

Gambar 2. Distribusi ukuran pori karbon hasil pirolisis kulit manggis dan limbah sisa ekstraksi kulit manggis: (a) Metode HK dan (b) Metode BJH 
Pada Gambar 2(a) terlihat bahwa karbon dari kulit manggis memiliki distribusi ukuran pori yang seragam dan terletak pada daerah 0,7-0,9 nm. Sedangkan untuk karbon dari limbah sisa ekstraksi kulit manggis tidak memperlihatkan adanya puncak pada daerah tersebut karena karbon tersebut merupakan karbon mesopori. Pada Gambar 2(b) dapat dilihat bahwa untuk karbon dari limbah sisa ekstraksi kulit manggis memiliki daerah diantara 2-100 nm dengan puncak tertinggi terletak pada daerah $9 \mathrm{~nm}$. Selain itu, dapat diketahui bahwa karbon dari limbah kulit manggis sisa ekstraksi memiliki porsi yang besar pada bagian meso atau diameter antara $2-50 \mathrm{~nm}$.

\section{Karakteristik Karbon Teremban Cobalt}

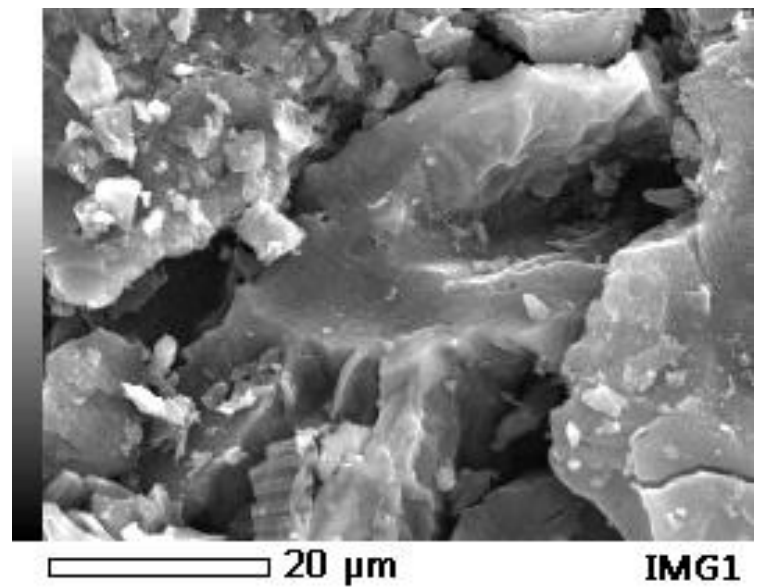

(a)

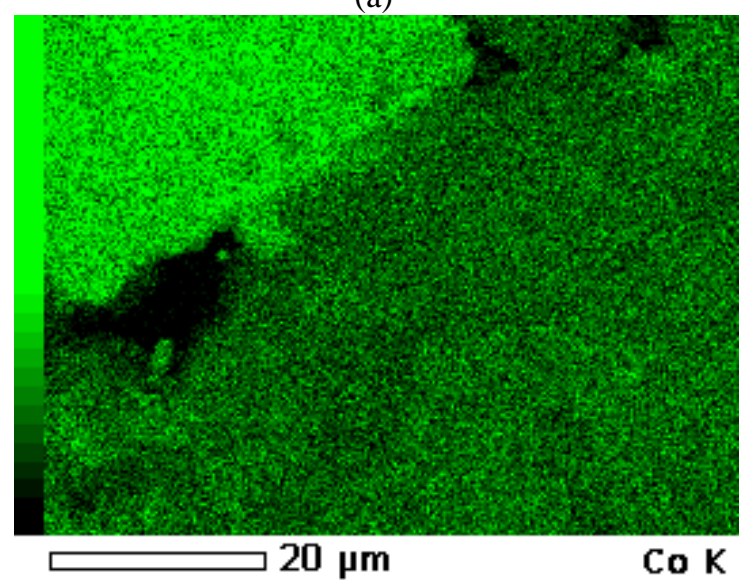

(b)

Gambar 3. Pemetaan cobalt pada permukaan karbon dengan analisis SEM-EDX

Distribusi oksida cobalt pada permukaan karbon merupakan aspek yang cukup penting dalam proses impregnasi oksida cobalt pada permukaan karbon. Distribusi logam yang merata pada permukaan karbon akan memaksimalkan proses penjerapannya. Untuk jumlah komposisi yang sama, jika terjadi aglomerasi pada permukaan karbon maka jumlah etilen yang terjerap akan berkurang dibandingkan jika logam dapat tersebar merata pada permukaan karbon. Hal ini dikarenakan permukaan aktif yang digunakan untuk menjerap akan berkurang sehingga penjerapannya menjadi kurang efektif yang berakibat pada jumlah etilen yang terjerap menjadi lebih sedikit. Oleh karena itu distribusi logam pada permukaan karbon penting untuk diketahui. Untuk melihat pemetaan logam pada permukaan karbon dilakukan analisis menggunakan analisis SEM-EDX. Hasil analisis SEM-EDX dapat dilihat pada Gambar 3.

Gambar 3(a) merupakan foto SEM dari karbon yang telah teremban cobalt. Gambar 3(b) merupakan analisis elemental mapping SEM-EDX untuk Co pada permukaan karbon. Warna hijau menunjukkan keberadaan Co pada permukaan karbon. Dari Gambar dapat dilihat bahwa Cobalt dapat tersebar cukup baik pada permukaan karbon.

\section{Hasil Uji Adsorpsi Etilen}

Uji adsorpsi diawali dengan melakukan adsorpsi etilen pada karbon dari kulit manggis dan limbah sisa ekstraksi kulit manggis tanpa pengembanan oksida cobalt. Gambar 4 menyajikan hasil uji adsorpsi untuk karbon dari kulit manggis dan limbah sisa ekstraksi kulit manggis serta karbon teremban oksida cobalt dengan komposisi 30\%. Dari data percobaan seperti pada Gambar 4 dilakukan evaluasi menggunakan beberapa persamaan kesetimbangan. Nilai-nilai parameter untuk model kesetimbangan adsorpsi yang digunakan disajikan pada Tabel 4.

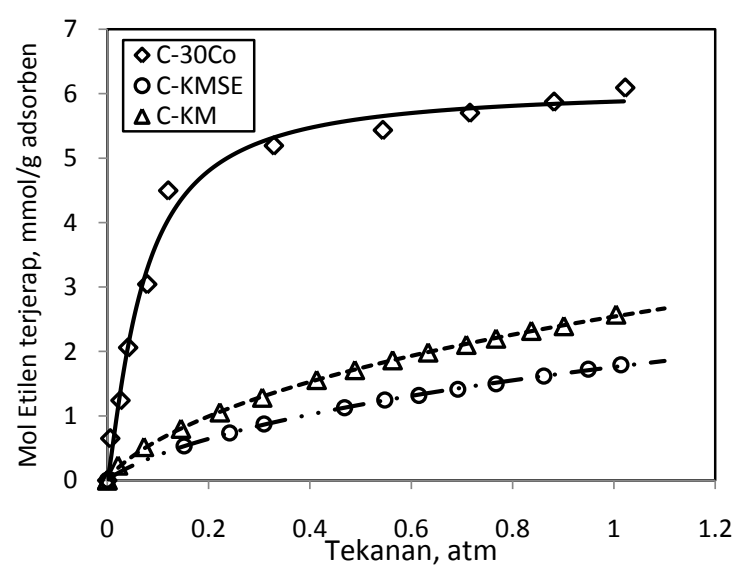

Gambar 4. Kurva isoterm adsorpsi etilen pada berbagai jenis karbon pada $\mathrm{T}=30^{\circ} \mathrm{C}$

Gambar 4 memberikan informasi bahwa karbon dari kulit manggis memiliki kemampuan menjerap etilen lebih baik dibandingkan karbon dari limbah sisa ekstraksi kulit manggis. Hal ini dikarenakan karbon dari kulit manggis merupakan karbon mikropori dengan distribusi ukuran pori dari karbon kulit manggis (7-9 $\AA$ atau 0,7-0,9 nm) mendekati ukuran molekul etilen $(4,163 \AA)$. Pada karbon dari limbah sisa ekstraksi kulit manggis yang merupakan karbon mesopori dengan distribusi ukuran porinya terletak antara 2-50 nm, jarak antara etilen dengan permukaan karbon lebih jauh yang menyebabkan afinitas adsorben terhadap adsorbat 
Tabel 4. Nilai parameter kesetimbangan adsorpsi etilen berbagai karbon pada suhu $30^{\circ} \mathrm{C}$

\begin{tabular}{|c|c|c|c|}
\hline \multirow[t]{2}{*}{ Parameter kesetimbangan Adsorpsi } & \multicolumn{3}{|c|}{ Jenis Karbon } \\
\hline & $\mathrm{C}-\mathrm{KM}$ & C-KMSE & C-30Co \\
\hline \multicolumn{4}{|l|}{ Persamaan Langmuir } \\
\hline $\mathrm{C} \mu \mathrm{s}, \mathrm{mmol} / \mathrm{g}$ adsorben & 4,1307 & 3,1808 & 6,4457 \\
\hline $\mathrm{b}, \mathrm{atm}^{-1}$ & 1,5120 & 1,1998 & 12,5488 \\
\hline \multicolumn{4}{|l|}{ Persamaan Freundlich } \\
\hline $\mathrm{K}, \mathrm{mmol} /(\mathrm{g}$ adsorben.atm $)$ & 2,2057 & 1,6196 & 7,2519 \\
\hline $\mathrm{n}$ & 2,1541 & 1,8361 & 2,3374 \\
\hline \multicolumn{4}{|l|}{ Persamaan Toth } \\
\hline $\mathrm{C} \mu \mathrm{s}, \mathrm{mmol} / \mathrm{g}$ adsorben & 19,9594 & 14,4335 & 5,9365 \\
\hline $\mathrm{b}, \mathrm{atm}^{-1}$ & 0,8456 & 0,5834 & 9,5910 \\
\hline $\mathrm{t}$ & 0,3508 & 0,3805 & 1,5730 \\
\hline \multicolumn{4}{|l|}{ Persamaan Sips } \\
\hline $\mathrm{C} \mu \mathrm{s}, \mathrm{mmol} / \mathrm{g}$ adsorben & 11,4646 & 8,7359 & 6,090 \\
\hline $\mathrm{b}, \mathrm{atm}^{-1}$ & 0,1623 & 0,1479 & 14,3798 \\
\hline $\mathrm{n}$ & 1,4545 & 1,3929 & 0,8033 \\
\hline \multicolumn{4}{|l|}{ Persamaan Unilan } \\
\hline $\mathrm{C} \mu \mathrm{s}, \mathrm{mmol} / \mathrm{g}$ adsorben & 4,1308 & 3,1809 & 6,4457 \\
\hline $\mathrm{b}, \mathrm{atm}^{-1}$ & 1,5119 & 1,1998 & 12,5487 \\
\hline $\mathrm{s}$ & 0,0119 & 0,0143 & 0,0083 \\
\hline
\end{tabular}

menjadi rendah sehingga jumlah etilen yang terjerap lebih sedikit. Jarak antara adsorbat dengan adsorben yang semakin dekat akan meningkatkan afinitas dari adsoben terhadap adsorbat. Peningkatan afinitas tersebut menyebabkan jumlah adsorbat yang terjerap pada permukaan adsorben juga semakin meningkat.

Melihat kapasitas penjerapan dari karbon kulit manggis dan limbah sisa ekstraksi kulit manggis yang masih rendah, maka dilakukan peningkatan kapasitas penjerapan dari karbon tersebut dengan menambahkan suatu garam logam pada permukaannya. Logam cobalt dipilih sebagai logam yang digunakan untuk menjerap etilen. Dalam hal ini logam cobalt yang digunakan untuk menjerap etilen merupakan cobalt dalam bentuk oksidanya. Garam cobalt memiliki ukuran yang cukup besar yaitu antara 7-8 ̊. Ukuran pori dari karbon kulit manggis memiliki ukuran yang sama dengan ukuran garam cobalt sehingga dimungkinkan akan menyumbat atau menutupi jaringan pori dari karbon tersebut. Sedangkan ukuran pori dari karbon limbah sisa ekstraksi kulit manggis berkisar antara 2-50 nm. Oleh karena itu, proses pengembanan oksida cobalt dilakukan menggunakan karbon dari limbah sisa ekstraksi kulit manggis. Dengan menggunakan karbon limbah sisa ekstraksi kulit manggis diharapkan semua garam logam yang ditambahkan dapat masuk ke dalam pori bagian dalam dan tidak ada yang menyumbat atau menutupi pori karbon.

Dari Gambar 4 juga dapat diketahui bahwa penambahan oksida cobalt pada permukaan karbon cukup efektif untuk meningkatkan kemampuan adsorpsi terhadap etilen. Terlihat dari perbedaan jumlah etilen yang terjerap cukup signifikan antara karbon tanpa pengembanan oksida cobalt dengan karbon teremban oksida cobalt.

\section{Pengaruh Perbedaan Garam}

Langkah yang selanjutnya dilakukan adalah pemilihan garam cobalt yang paling efektif dalam membentuk oksida cobalt. Dalam penelitian ini digunakan garam $\mathrm{Co}\left(\mathrm{NO}_{3}\right)_{2}, \mathrm{CoCl}_{2}, \mathrm{CoSO}_{4}$ dan $\mathrm{KMnO}_{4}$. Perbedaan kapasitas penjerapan dari beberapa garam tersebut disajikan pada Gambar 5.

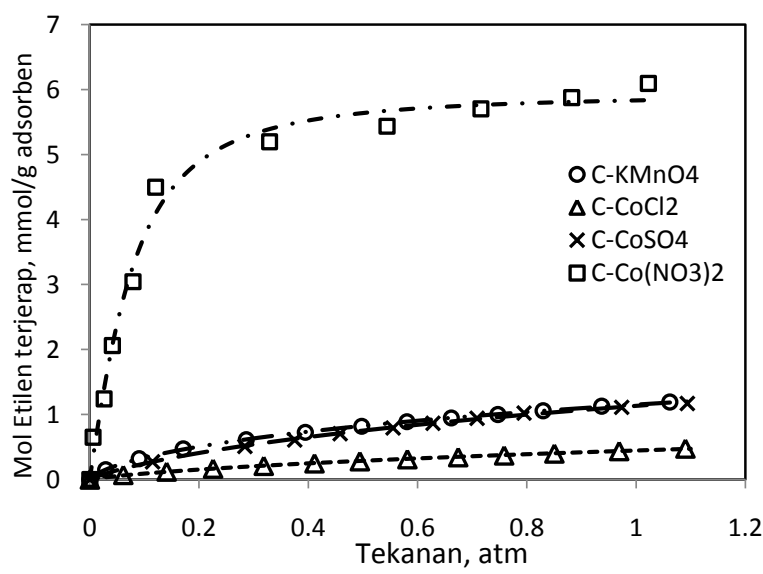

Gambar 5. Kurva isoterm adsorpsi etilen pada karbon teremban dengan berbagai garam

$\mathrm{KMnO}_{4}$ merupakan bahan yang sering digunakan secara komersial dalam proses penjerapan etilen, sehingga penggunaan $\mathrm{KMnO}_{4}$ dalam penelitian ini digunakan sebagai pembanding dengan garam cobalt yang digunakan. Pada Gambar 5 dapat dilihat bahwa garam $\mathrm{Co}\left(\mathrm{NO}_{3}\right)_{2}$ mempunyai kemampuan penjerapan yang lebih baik dari garam yang lain. Dilihat dari ukuran molekulnya, $\mathrm{Co}\left(\mathrm{NO}_{3}\right)_{2}$ berukuran 7,9 $\AA$ sedangkan untuk $\mathrm{CoCl}_{2}, \mathrm{CoSO}_{4}$ dan $\mathrm{KMnO}_{4}$ secara berturut-turut yaitu 7,32 $\AA$; 7,7 $\AA$ dan $5,7 \AA$. Jadi dapat disimpulkan bahwa untuk keempat garam tersebut dapat masuk ke dalam jaringan rongga pori dari material karbon berpori yang berdiameter ratarata $5 \mathrm{~nm}$. Sedangkan jika dilihat dari proses kalsinasinya, pada penelitian ini digunakan suhu kalsinasi sebesar $200^{\circ} \mathrm{C}$. Suhu dekomposisi maksimum $\mathrm{Co}\left(\mathrm{NO}_{3}\right)_{2}$ menjadi oksida cobalt yaitu $270^{\circ} \mathrm{C}$ (Stern, 1972). Sedangkan proses dekomposisi garam $\mathrm{CoCl}_{2}$ dan $\mathrm{CoSO}_{4}$ membentuk oksida cobalt 
memerlukan suhu yang lebih tinggi. Suhu dekomposisi untuk $\mathrm{CoCl}_{2}$ dan $\mathrm{CoSO}_{4}$ secara berturutturut yaitu $400^{\circ} \mathrm{C}$ dan $735^{\circ} \mathrm{C}$ (WHO, 1991). Oleh karena itu $\mathrm{CoCl}_{2}$ dan $\mathrm{CoSO}_{4}$ yang terkonversi menjadi oksida cobalt masih sedikit atau belum sempurna. Hal inilah yang menyebabkan kapasitas penjerapan etilen untuk C-CoCl 2 dan $\mathrm{CoSO}_{4}$ menjadi lebih rendah.

\section{Pengaruh Perbedaan Komposisi Cobalt Teremban}

Pengaruh pebedaan komposisi cobalt terhadap kapasitas penjerapan etilen disajikan pada Gambar 6. Dari Gambar 6 terlihat bahwa dengan semakin banyaknya cobalt yang teremban pada permukaan karbon maka jumlah etilen yang terjerap juga akan semakin meningkat. Hal ini disebabkan karena jumlah situs aktif yang dapat mengikat etilen juga semakin banyak sehingga etilen yang terikat juga akan semakin banyak. Dari Gambar 6 juga dapat dilihat bahwa karbon yang teremban $30 \%$ cobalt memiliki kapasitas penjerapan yang paling banyak. Hal ini sesuai dengan penelitian yang telah dilakukan oleh Li (2013). Dalam penelitiannya, Li (2013) menyatakan bahwa karbon teremban $30 \%$ cobalt memiliki nilai kapasitas yang paling baik.

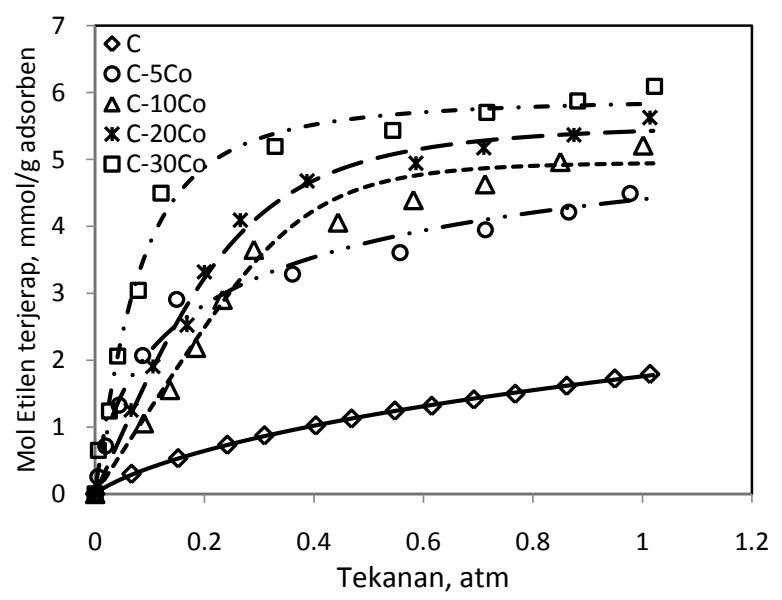

Gambar 6. Kurva isoterm adsorpsi etilen pada C$\mathrm{Co}\left(\mathrm{NO}_{3}\right)_{2}$ dengan variasi komposisi

\section{Pengaruh Perbedaan Suhu}

Gambar 7 menyajikan hasil penelitian tentang pengaruh penjerapan etilen pada permukaan karbon teremban 5\% cobalt pada berbagai suhu. Pada Gambar 7 terlihat bahwa dengan meningkatnya suhu percobaan maka kapasitas penjerapannya semakin meningkat. Hal ini dikarenakan pada saat suhu dinaikkan maka reaktifitas permukaan oksida cobalt untuk mengikat etilen akan meningkat sehingga afinitas etilen pada permukaan oksida cobalt juga akan semakin meningkat. Oleh karena afinitas adsorbat pada permukaan adsoben meningkat maka jumlah adsorbat yang terjerap juga akan meningkat.

Dari data kesetimbangan adsorpsi seperti yang terlihat pada Gambar 7 dapat diperoleh nilai panas adsorpsi menggunakan Persamaan Clausius-Clapeyron (Do, 1998).

$$
\left(\ln \frac{\mathrm{P}_{2}}{\mathrm{P}_{1}}\right)_{\mathrm{C}_{\mu}}=-\frac{\Delta \mathrm{H}}{\mathrm{R}}\left(\frac{1}{\mathrm{~T}_{1}}-\frac{1}{\mathrm{~T}_{2}}\right)
$$

Pada daerah yang berlaku hukum Henry, $\mathrm{C}_{\mu}=\mathrm{K}_{\mathrm{P}} \mathrm{P}$, sehingga Persamaan (11) dapat diubah menjadi:

$$
\ln \frac{\mathrm{K}_{\mathrm{p}, 2}}{\mathrm{~K}_{\mathrm{p}, 1}}=-\frac{\Delta \mathrm{H}}{\mathrm{R}}\left(\frac{1}{\mathrm{~T}_{1}}-\frac{1}{\mathrm{~T}_{2}}\right)
$$

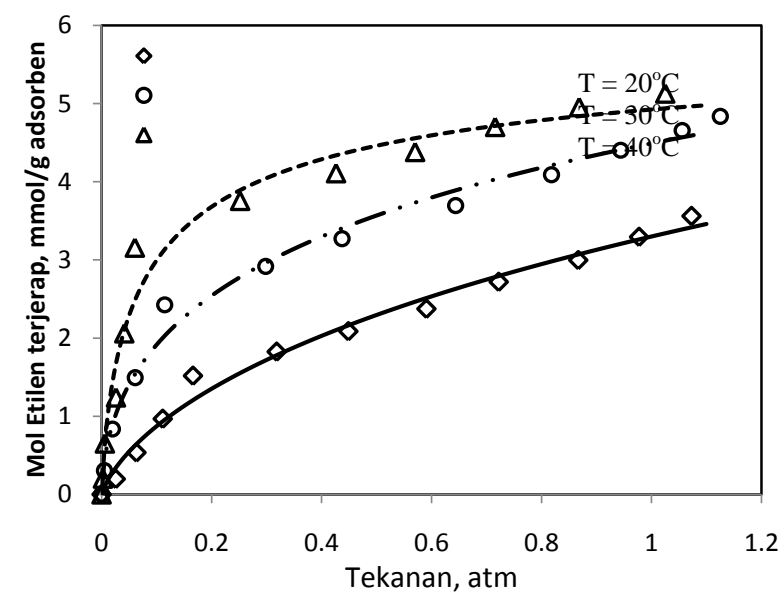

Gambar 7. Kurva isoterm adsorpsi etilen pada C-5Co pada berbagai suhu

Hasil perhitungan untuk konstanta Henry untuk berbagai suhu dan panas adsorpsi disajikan pada Tabel 5 dan disajikan pula dalam bentuk grafik hubungan antara $\ln (\mathrm{Kp})$ versus (1/T) seperti terlihat pada Gambar 8 .

Tabel 5. Konstanta Henry untuk adsorpsi etilen pada berbagai suhu

\begin{tabular}{ccc}
\hline $\begin{array}{c}\text { Suhu, } \\
\mathrm{K}\end{array}$ & Konstanta Henry, Kp & $\Delta \mathrm{H}, \mathrm{kJ} / \mathrm{mol}$ \\
\hline 293 & $1.14 \times 10^{-2}$ & 74,1 \\
303 & $3.32 \times 10^{-2}$ & \\
313 & $7.95 \times 10^{-2}$ & \\
\hline * dalam gmol/(gram.atm)
\end{tabular}

Panas adsorpsi etilen pada karbon teremban oksida cobalt pada penelitian ini adalah $74,1 \mathrm{~kJ} / \mathrm{mol}$. Dari nilai panas adsorpsi yang diperoleh ini menunjukkan bahwa terjadi peristiwa adsorpsi kimia antar etilen dengan oksida cobalt pada permukaan karbon. Panas adsorpsi kimia yang memiliki rentang nilai antara 40-400 kJ/mol (Fogler, 2011).

Selanjutnya adsorben yang dihasilkan digunakan untuk proses pengawetan buah untuk mengetahui seberapa efektif adsorben yang telah dibuat dalam memperpanjang umur simpan dari buah pisang Cavendish. Percobaan dilakukan pada suhu lingkungan $\left(20-32^{\circ} \mathrm{C}\right)$ dan pengamatan dilakukan dengan melihat perubahan warna kulitnya dari hari ke hari. Hasil pengamatan terhadap perubahan warna pisang Cavendish pada berbagai massa adsorben etilen menunjukkan bahwa semakin bertambahnya massa adsorben etilen yang digunakan maka waktu simpan dari buah semakin lama seperti terlihat pada Tabel 6 . 
Tabel 6. Tingkat perubahan warna kulit pada buah pisang cavendish

\begin{tabular}{|c|c|c|c|c|c|c|c|c|}
\hline \multirow{2}{*}{$\begin{array}{l}\text { Massa Adsorben, } \\
\text { gr/kg buah }\end{array}$} & \multicolumn{7}{|c|}{ Lama Penyimpanan, hari } & \multirow[t]{2}{*}{ Keterangan } \\
\hline & 0 & & 3 & 6 & 9 & 12 & 15 & \\
\hline 0 & & 2 & 5 & - & - & - & - & $\begin{array}{l}\text { hari ke- } 3 \text { buah rontok dari sisir dan hari pertama sudah } \\
\text { tumbuh jamur }\end{array}$ \\
\hline 2 & & 2 & 3 & 5 & - & - & - & $\begin{array}{l}\text { hari ke- } 7 \text { buah rontok dari sisir dan hari ke- } 6 \text { jamur } \\
\text { mulai tumbuh }\end{array}$ \\
\hline 5 & & 2 & 3 & 4 & 5 & - & - & $\begin{array}{l}\text { hari ke-10buah rontok dari sisir dan hari ke- } 8 \text { jamur } \\
\text { mulai tumbuh }\end{array}$ \\
\hline 10 & & 2 & 2 & 3 & 4 & 5 & - & hari ke-12 uah rontok dari sisir \\
\hline 15 & & 2 & 2 & 3 & 3 & 4 & 5 & hari ke-15 buah rontok dari sisir \\
\hline
\end{tabular}

1 = hijau; 2 = hijau $>$ kuning; 3 = hijau < kuning; 4 = kuning; 5 = kuning kecoklatan

Jumlah etilen yang berkurang akan menghambat proses pematangan dari buah pisang Cavendish. Waktu simpan terlama dihasilkan dari penyimpanan buah pisang Cavendish dengan penambahan 15 gram adsorben+silica gel. Penambahan silica gel dilakukan untuk mengurangi jumlah uap air yang terbentuk sebagai hasil dari proses metabolisme buah selama penyimpanan. Keberadaan uap air dapat memicu tumbuhnya jamur pada buah.

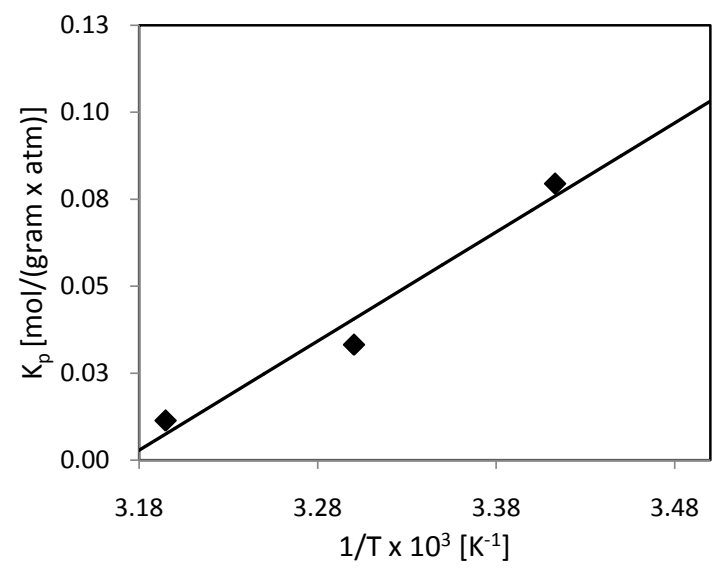

Gambar 8. Nilai konstanta Henry untuk adsorpsi etilen pada berbagai suhu

\section{KESIMPULAN}

Limbah sisa ekstraksi kulit manggis dapat digunakan sebagai bahan baku pembuatan karbon mesopori yang dapat digunakan sebagai penyangga oksida cobalt. Modifikasi permukaan karbon dengan penambahan oksida cobalt dapat meningkatkan kapasitas penjerapan etilen dimana kapasitas penjerapan etilen semakin meningkat dengan semakin bertambahnya komposisi oksida cobalt pada permukaan karbon. Penambahan karbon teremban oksida cobalt pada penyimpanan buah pisang Cavendish dapat memperpanjang umur simpannya dan semakin meningkat dengan bertambahnya jumlah adsorben.

\section{DAFTAR PUSTAKA}

Ahmad, M.A. and Alrozi, R., (2010, Optimization of Preparation Conditions for Mangosteen Peel Based Activated Carbon for The Removal of Remazol Brilliant Blue $\mathrm{R}$ Using Response Surface Methodology, Chem.Eng.Journal, 165, pp. 883-890.

Bailen, G., Guillen, F., Castillo, S., Zapata, P.J., Serrano, M., Valero, D., and Martinez-Romero, D., (2007), Use of Palladium Catalyst to Improve the Capacity of Activated Carbon to Absorb Ethylene and Its Effect on Tomato Ripening, Spanish Journal of Agicultural Research, pp. 579-586.

Barret, E.P., Joyner, L.G., and Halenda, P.P., (1951), The Determination of Pore Volume and Area Distributions in Porous Substances: I. Computations from Nitrogen Isotherms, J. Am. Chem. Soc., 73 (1), pp. 373-380

Bujang, A.S., (2014), Utilization of Durian Biomass of Biorenewable Aplications, Graduate Theses and Disertations, Iowa State University, Ames, Iowa, United States.

Cao, J., Li, X., Wu, K., Jiang, W., and Qu, G., (2014), Preparation of Novel $\mathrm{PdCl}_{2}-\mathrm{CuSO}_{4}$-Based Ethylene Scavanger Supported by Acidified Activated Carbon Powder and Its Effects on Quality and Ethylene Metabolism of Broccoli During Shelf-Life, Postharvest Biology and Technology, 99, pp. 50-57.

Chen, Y., Huang, B., Huang, M., and Cai, B., (2011), On the Preparation and Characterization of Activated Carbon from Mangosteen Shell, Journal of the Taiwan Institute of Chemical Engineers, 42, pp. 837-842.

Do, D.D., (1998), Adsorption analysis: Equilibria and Kinetics, Imperial College, London.

Fogler, H.S., (2011), Essentials of Chemical Reaction Engineering, Pearson Education Inc., London.

Kristianingrum, S., (2007), Beberapa Metode Pengawetan Buah, Laporan Penelitian, Universitas Negeri Yogyakarta, Yogyakarta, Indonesia. 
Li, W., Qiu, Z., Chen, H., Wang, J., Long, D., Qiao, W., and Ling, L., (2013), Preparation of Cobalt Oxide Supported Mesoporous Carbon Spheres for Ethylene Removal.

Mukti, N.I.F., Prasetyo, I., and Mindaryani, A., (2015), Preparation of Ethylene Adsorbent by Pyrolysis of Mangosteen Peels, Prosiding Seminar SNTKI V, Yogyakarta.

Okhovat, A., Ahmadpour, A., Ahmadpour, F., and Yadegar, Z.K., (2012), Pore Size Distribution Analysis of Coal-Based Activated Carbons: Investigating the Effects of Activating Agent and Chemical Ratio, International Scholary Research Network, 2012 (10), pp. 1-10.

Saidur, R., Abdelaziz, E. A., Demirbas, A., Hossain, M. S., and Mekhilef, S., (2011), A Review on Biomass as a Fuel for Boilers, Renewable an Sustainable Energy Reviews, 15, pp. 2262-2289.

Setyadjit, Sukasih, E., dan Permana, A.W., (2012), Aplikasi 1-MCP Dapat Memperpanjang Umur Segar Komoditas Hortikultura, Balai Besar Penelitian dan Pengembangan Pascapanen Pertanian, Bogor.
Shawal, N.N., Jibril, M., Abbas, A.Z.M., Dadum, H.U., Husna, M.Z., and Nasir, A.F., (2014), Characteristics of Potassium Acetate-Activated Coconut Shell Carbon, Advanced Materials Research, 1043, pp. 193-197.

Smith, A.W.J., Poulston, S., and Rowsell, L., (2009), New Palladium-Based Ehylene Scavanger to Control Ethylene-Induced Ripening of Climateric Fruit, Platinum Metal Rev., 53, pp. 112-122.

Stern, K.H., (1972), High Temperature Properties and Decomposition of Inorganic Salts Part 3.Nitrates and Nitrites, J. Phys. Chem. Ref. Data, 1(3), pp. 747-772.

Sue-Aok, N., Srithanratana, T., Rangsriwatananon, K., and Hengrasmee, S., (2010), Study of Ethylene Adsorption on Zeolite NaY Modified With Group I Metal Ion, Applied Surface Science, 256, pp. 39974002.

World Health Organization, (1991), Cobalt and Cobalt Compound, Iarc Monographs, 52, pp. 363-473. 